\title{
NONSPECIFIC RESISTANCE IN HEIFERS AND CALVES UNDER CONDITIONS OF TECHNOGENIC LOAD AND UNDER THE INFLUENCE OF CORRECTION FACTORS
}

\author{
I. Matiukha, N. Broda, D. Mudrak, K. Smolyaninov \\ iramatiukha@gmail.com
}

Institute of Animal Biology NAAS,

38 V. Stus str., Lviv 79034, Ukraine

Environmental contamination by xenobiotics has a crucial negative impact on productive animals' health by reducing immune reactivity and causing metabolic disorders. One of the ecologically dangerous objects in Ukraine is the Lviv-Volyn coal basin. Thus the aim of our study was to investigate the influence of subcutaneous injections of vitamin drug in liposomal form on the performance, antioxidant and immune status of heifers and their calves under technogenic load. Investigation and the explanation of the influence of experimental drug "Pregnavitan" on the intensity of metabolism of vital important vitamins $A$ and E, intensity of antioxidant defense in cows and their calves was the main aim of our work. The research has showed the tendency to growing the number of leucocytes, and the decrease of total protein content and current indexes of cell and humoral links of immune defense with the increase of gestation time in the blood of cow's established. This suggests the development of physiological immunosuppresion in pregnant animals. Intramuscular injection in the last month of pregnancy of vitamins $A, D_{3}$, E, lecithin, methionine and cobalt acetate in the form of liposomal emulsion improves natural resistance of cows and received of them calves. The parenteral injection of liposomal drug "Pregnavitan" to pregnant cows and newborn calves enhances the natural resistance of their organisms and recovery red-ox balance in their body. In these circumstances, the drug we have developed for the needs of animals: essential vitamins, trace elements and biologically active substances. In general, that composition had positive effects on metabolic processes in animals.

\section{Keywords: COWS, CALVING, LIPOSOMALEMULSION, VITAMINS, MINERALS}

\section{НЕСПЕЦИФІЧНА РЕЗИСТЕНТНІСТЬ НЕТЕЛЕЙ ТА ТЕЛЯТ ЗА УМОВ ТЕХНОЛОГІЧНОГО НАВАНТАЖЕННЯ ТА ПІД ВПЛИВОМ КОРЕКЦІЙНИХ ФАКТОРІВ}

\author{
I. Матюха, Н. Брода, Д. Мудрак, К. Смолянінов \\ iramatiukha@gmail.com
}

Інститут біології тварин НААН,

вул. В. Стуса, 38, м. Львів, 79034, Україна

Забруднення навколишнього середовища ксенобіотиками має вирішальний негативний вплив на здоров'я продуктивних тварин, що призводить до зниження імунної реактивності та спричиняє порушення обміну речовин. Одним з екологічно-небезпечних об'єктів в Україні є Львівсько-Волинський вугільний басейн. Таким чином, метою намого дослідження було дослідити вплив підшкірних ін'єкиій вітамінного препарату у ліпосомальній формі на продуктивність, антиоксидантний та імунний статус нетелей та їхніх телят за техногенного навантаження. Дослідження та пояснення впливу експериментального препарату «Прегнавітан» на інтенсивність метаболізму жсттево важливих вітамінів А та E, інтенсивність антиоксидантного захисту у корів та їх телят було головною метою нашої роботи. Дослідження показало тенденцію до збільшення кількості лейкочитів, зменшення загального вмісту білка та основних показників клітинної та гуморальної ланки імунного захисту зі збільшенням часу гестації в крові корови. Це говорить про розвиток фізіологічної імуносупресії у тільних тварин. Внутрішньом'язове введення в останній місяиь тільності вітамінів $A, D_{3}$, E, лецитину, метіоніну та ацетату кобальту у вигляді ліпосомальної емульсї̈ покрашує природну стійкість корів та одержуваних від них телят. Парентеральне введення ліпосомного препарату «Прегнавітан» тільним коровам і новонародженим телятам підвищує природну стійкість їхнього організму та відновлення його окисно-відновного балансу. Досліджений у ицих умовах препарат для потреб тварин містить есенціальні вітаміни, мікроелементи та біологічно активні речовини.

Ключові слова: КОРОВИ, ТЕЛЯТА, ЛІПОСОМАЛЬНА ЕМУЛЬСІЯ, ВІТАМІНИ, МІНЕРАЛИ 


\title{
НЕСПЕЦИФИЧЕСКАЯ РЕЗИСТЕНТНОСТЬ ТЕЛОК И ТЕЛЯТ В УСЛОВИЯХ ТЕХНОЛОГИЧЕСКОЙ НАГРУЗКИ И ПОД ВЛИЯНИЕМ КОРРЕКЦИОННЫХ ФАКТОРОВ
}

\author{
И. Матюха, Н. Брода, Д. Мудрак, К. Смолянинов \\ iramatiukha@gmail.com
}

Институт биологии животных НААН,

ул. Стуса, 38, г. Львов, 79034, Украина

Загрязнение окружающей среды ксенобиотиками оказывает решающее негативное влияние на здоровье продуктивных животных, что приводит к снижению иммунной реактивности и вызывает нарушение обмена веществ. Одним из экологически опасных объектов в Украине является Львовско-Волынский угольный бассейн. Таким образом, целью нашего исследования было изучить влияние подкожных инъекиий витаминного препарата в липосомальной форме на продуктивность, антиоксидантный и иммунныій статус нетелей и их телят при техногенной нагрузке. Исследования и объяснения влияния экспериментального препарата «Прегнавитан» на интенсивность метаболизма жизненно важных витаминов А и Е, интенсивность антиоксидантной зашиты у коров и их телят было главной целью намей работы. Исследование показало тенденцию к увеличению количества лейкоцитов, уменьшение общего содержания белка и основных показателей клеточного и гуморального звена иммунной защиты с увеличением продолжительности стельности в крови коровы. Это говорит о развитии физиологической иммуносупрессии у беременных животных. Введение в последний месяи стельности витаминов $A, D_{3}$, E, лецитина, метионина и ацетата кобальта в виде липосомальной эмульсии улучшает естественную устойчивость коров и получаемых от них телят. Парентеральное введение липосомного препарата «Прегнавитан» стельным коровам и новорожденным телятам повышает естественную устойчивость их организма и восстановление его окислительно-восстановительного баланса. Исследованный в этих условиях препарат для нужд животных содержит эссенциальные витамины, микроэлементы и биологически активные вещества.

\section{Ключевые слова: КОРОВЫ, ТЕЛЯТА, ЛИПОСОМАЛЬНАЯ ЭМУЛЬСИЯ ВИТАМИНЫ}

Pollution of environment by chemical xenobiotic has a negative impact on the status of productive animal health by reducing immune reactivity and metabolic disorders [3]. One of the ecologically dangerous objects of the state-level is the Lviv-Volyn coal basin where 101.5 million $\mathrm{m}^{3}$ of waste products is stored [10]. All this contributes to suppression of natural resistance, reduced reproductive ability of animals, development of immunodeficiency state. Unfortunately, the active protection of calves, which is based on a natural resistance and application of specific prevention, limited by physiological immunodeficiency of newborn animals and the development of metabolic disorders, among which an important place has the imbalance of pro- and antioxidant and other important body systems [11]. In recent years, medicine intensively studied a new way directional transport of drugs in the body by using them as liposomal drugs [2]. Thus, the alternative and safe methods of increasing of reproductive system in animals with liposomes are discussed now.
Considering the above-said, the aim of the study was to investigate the influence of subcutaneous injections of vitamin drug in liposomal forms on the performance, antioxidant and immune status of heifers and their calves. Investigate and the explain the influence of experimental drug "Pregnavitan" on the intensity of metabolism of vital important vitamins A and E, intensity of antioxidant defense in cows and their calves was the main aim of our work.

\section{Materials and methods}

The studies were conducted in Sokal district, Lviv region in two stages. The $1^{\text {st }}$ stage of investigation was conducted on two groups of cows at last month of pregnancy and on their calves. The animals were divided into control and experimental groups of 7 cows in each group. Cows of experimental group at 30 and 14 days before calving were intramuscularly injected by liposomal drug "Pregnavitan" in the dose of $0.04 \mathrm{ml}$ per $\mathrm{kg}$ of the body weight, cows in the control group - isotonic 
sodium chloride in the dose of $10 \mathrm{ml}$ per animal. The composition of the drug "Pregnavitan" includes: tocopherol acetate, squalene, lecithin, methionine, L-arginine, sodium selenite, oil from the fruit thistle, buckthorn and flax seeds in medical doses. In the $2^{\text {nd }}$ experiment stage the calves that were born from cows of research group at the 3- and 14-day age were intramuscularly injected by drug in dose of $0.04 \mathrm{ml}$ per $\mathrm{kg}$ of body weight, animals in the control group - according isotonic sodium chloride solution.

Blood samples for immunological and biochemical studies were taken from the jugular vein of heifers on 30,14 and 7 days before the calving, and from calves in 3-, 14- and 28-day age. The activity of humoral links of immune defense was counted. Lysocyme activity (LABS) to a Micrococcus lysodeikticus (strain VKM-109), by photonepelometric method, bactericidal activity (BABS), complementary activity by the unified method, the content of circulating immune complexes (CIC) in serum were determined. [6]. The data was statistically processed using Microsoft Excel and Statistica 6.0. The differences between the values were considered statistically significant: $\mathrm{P}<0.05 ; \mathrm{P}<0.01$ and $\mathrm{P}<0.001$.

\section{Results and discussion}

The basis of the metabolic immune deficiency is the development of atrophy and apoptosis of lymphoid tissues of the bone marrow, lymph nodes and spleen, blood lymphocytes, and other lymphoid organs, causing a decrease in nonspecific resistance and immune reactivity [2]. Due to the functioning of the Chervonohrad mining complex, tons of rock exported from coal mines has formed dozens of waste heaps - the main sources of water pollution. The substrate of dumps contains a significant amount of the sulfur formed during the decomposition of pyrite $\left(\mathrm{FeS}_{2}\right)$ with the formation of sulfuric acid and sulfate solutions and are characterized by high acidity and high content of heavy metals, which is usually significantly higher than the maximum allowable concentrations. Studies of subterminal water samples were carried out by a separate subdivision of the "Zakhidvuhlepromsanecologia" department, which found that certain indicators did not relevant to the requirements.
In particular, it was found that in water the dry residue exceeds the allowable value in 1.03-2.32 times, the content of sulfates in 1.36-1.61 times, manganese in the range of 4.7-43.9 times.

One of the biological methods for assessing the state of the environment is bioindication with the help of plants. Plants are preferred because they are a very convenient object for biological monitoring of the state of the environment, because they characterize the state of the environment in which they grow, multiply rapidly, and react differently to the action of harmful factors. This allows us to choose the most appropriate reaction for specific study [7]. The analysis of soil condition in the Chervonohrad mining industry shows that the level of inhibition of the growth processes of phytoindicators in the testing ground for Sosnivka village is $45 \%$, the phytotoxic effect (mean value for the landfill) is $43.6 \%$, which exceeds the average permissible indicator [5].

The results of studies of heavy metals' content in the blood of cows in the farm, which is located in the zone of technogenic loading, are presented in table 1. Exceeding the maximum permissible concentration of manganese, zinc, copper, lead, and cobalt respectively in $1.2 ; 2.2 ; 1.3 ; 5.7$ and 8.2 times was shown. The content in blood of such an important macroelement, as Calcium was in 2.6 times less than the required minimum concentration. Calcium is known to promote the removal of heavy metal salts and radionuclides from the body, has anti-allergic effects, it is a probiotic and performs antioxidant functions.

Table 1

Content of mineral elements in the blood of cows under technogenic load $(M \pm m,=10)$

\begin{tabular}{|l|c|c|c|}
\hline \multirow{2}{*}{ Indices } & $\begin{array}{c}\text { Units } \\
\text { of measurement }\end{array}$ & $\begin{array}{c}\text { Maximum } \\
\text { permissible } \\
\text { concentration }\end{array}$ & Obtained data \\
\hline \multirow{2}{*}{$\mathrm{Mn}$} & $\mu \mathrm{g} \%$ & $15-25$ & $31.00 \pm 11.82$ \\
\cline { 2 - 4 } & $\mathrm{mmol} / 1$ & $2.73-4.55$ & $5.64 \pm 2.15$ \\
\hline \multirow{2}{*}{$\mathrm{Zn}$} & $\mu \mathrm{g} \%$ & $97-150$ & $322.38 \pm 29.51$ \\
\cline { 2 - 4 } & $\mathrm{mmol} / 1$ & $15-23$ & $49.65 \pm 4.54$ \\
\hline \multirow{2}{*}{$\mathrm{Cu}$} & $\mu \mathrm{g} \%$ & $80-130$ & $175.77 \pm 34.79$ \\
\cline { 2 - 4 } & $\mathrm{mmol} / 1$ & $12.6-22$ & $27.66 \pm 5.47$ \\
\hline \multirow{2}{*}{$\mathrm{Pb}$} & $\mu \mathrm{g} \%$ & $1.86-6.63$ & $37.86 \pm 4.95$ \\
\cline { 2 - 4 } & $\mathrm{mmol} / 1$ & $0.09-0.32$ & $1.83 \pm 0.24$ \\
\hline \multirow{2}{*}{$\mathrm{Co}$} & $\mu \mathrm{g} \%$ & $2.1-5.0$ & $40.93 \pm 3.67$ \\
\cline { 2 - 4 } & $\mathrm{mmol} / 1$ & $0.36-0.85$ & $6.96 \pm 0.62$ \\
\hline \multirow{2}{*}{$\mathrm{Ca}$} & $\mu \mathrm{g} \%$ & $9.5-12.5$ & $3.71 \pm 0.66$ \\
\cline { 2 - 4 } & $\mathrm{mmol} / 1$ & $2.4-3.12$ & $2.05 \pm 1.17$ \\
\hline
\end{tabular}


In immunodeficient conditions associated with pregnancy, in the mother's body there are some negative changes that manifest themselves by a decrease in cellular and humoral protective factors. The reason for these disorders in the body of cows is the physiological immunosuppression that develops in pregnant animals, as well as the harmful effects of factors of man-caused load caused by human economic activity.

Investigation of the influence of individual compounds of heavy metals on the state of non-specific resistance of the body of white rats showed a violation of cellular and humoral components, both in the short-term and long-term intake. The detected changes in the parameters depended on the dose and exposure time of these metals and had a phase nature (from suppression-suppression to stimulation).

Our studies have shown that the activity of humoral factors protection was reduced in the blood of control group during the research period. As is known, in immunodeficient conditions in pregnant animals, the level of complement and individual classes of immunoglobulins decreases, and the blood content of circulating immune complexes increases. Such links of natural protection of the organism as bactericidal activity of serum and phagocytic activity of blood neutrophils are reduced.

In cows, which for 30 and 14 days before calving were injected by the liposomal emulsion, positive dynamics of indices of the humoral level of non-specific resistance was noted (fig.). In particular, in serum of experimental group, the content of circulating immune complexes was less $(\mathrm{P}<0.05)$ in 7 days to the genera than in the control group.

Activation of the complement plays an important role in the body, promotes increased phagocytosis, chemotaxis and cytolysis. Probably the lower titer of the complement in animals in the experimental group for 7 days prior to calving indicates a higher TCR compared to the control group.

The conducted researches revealed a probable decrease in BABS in animals of the control group for 14 days prior calving in comparison to the month before $(\mathrm{P}<0.05)$. The two-times administration of the study drug resulted in a significant increase in the bactericidal activity of the blood
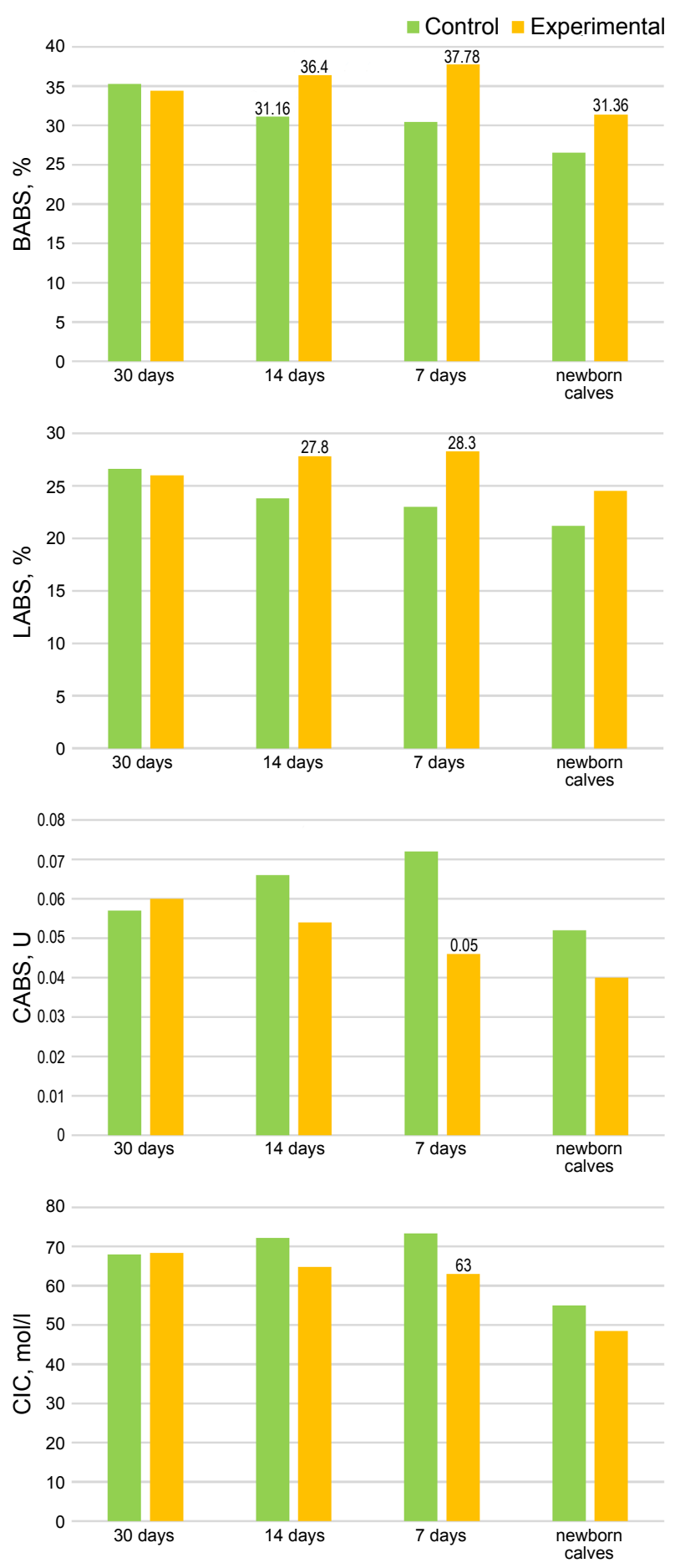

Fig. Humoral factors of natural defense in cows and their calves $(\mathrm{M} \pm \mathrm{m}, \mathrm{n}=3-5)$

serum in cows at 14 and 7 days before calving and in their calves at 3 days of life. The level of lysozyme activity of blood serum in cows of the experimental group for 14 and 7 days prior to calving was higher $(\mathrm{P}<0.05)$ than in the control group of animals (fig.).

Due to the normalization of metabolic processes, the positive dynamics of indices of the humoral non-specific resistance of calves was 
noted for the two-time parenteral administration to cows and newborn calves of the "Pregnavitan". In particular, in the blood serum of animals of the experimental group during the whole period of studies, somewhat higher content of circulating immune complexes of the average molecular weight was noted than in the control, indicating the stimulation of the immunobiological reactivity of the calf organism (table 2).

Table 2

Humoral factors of natural defense in cows and their calves $(M \pm m, n=3-5)$

\begin{tabular}{|l|c|c|c|c|}
\hline \multirow{2}{*}{ Indices } & \multirow{2}{*}{ Groups } & \multicolumn{3}{|c|}{ Age, days } \\
\cline { 2 - 5 } & & 3 & 14 & 28 \\
\hline $\begin{array}{l}\text { CIC, } \\
\text { mol/1 }\end{array}$ & $\mathrm{C}$ & $43.80 \pm 1.56$ & $45.20 \pm 1.28$ & $47.25 \pm 3.07$ \\
\cline { 2 - 5 } & $\mathrm{E}$ & $45.25 \pm 2.06$ & $48.75 \pm 2.75$ & $50.25 \pm 2.02$ \\
\hline $\begin{array}{l}\mathrm{CABS}, \\
\mathrm{U}\end{array}$ & $\mathrm{C}$ & $0.053 \pm 0.005$ & $0.058 \pm 0.006$ & $0.060 \pm 0.008$ \\
\cline { 2 - 5 } & $\mathrm{E}$ & $0.040 \pm 0.004$ & $0.038 \pm 0.005^{*}$ & $0.043 \pm 0.006$ \\
\hline $\begin{array}{l}\mathrm{BABS}, \\
\%\end{array}$ & $\mathrm{C}$ & $27.65 \pm 2.52$ & $28.05 \pm 1.87$ & $29.28 \pm 2.10$ \\
\cline { 2 - 5 } & $\mathrm{E}$ & $33.53 \pm 1.60$ & $35.11 \pm 2.48$ & $37.24 \pm 1.67 *$ \\
\hline $\begin{array}{l}\mathrm{LABS}, \\
\%\end{array}$ & $\mathrm{C}$ & $20.25 \pm 1.65$ & $21.75 \pm 1.25$ & $23.25 \pm 1.49$ \\
\cline { 2 - 5 } & $\mathrm{E}$ & $22.50 \pm 1.55$ & $26.25 \pm 1.31 *$ & $27.75 \pm 1.93$ \\
\hline
\end{tabular}

The high bactericidal activity of the blood serum is associated with the content of lysozyme, which has a cytolytic property in relation to microorganisms. It is capable, on the one hand, of the enzyme to break the bond between $\mathrm{N}$-acetylmuramic acid and $\mathrm{N}$-acetylglucosamine, and on the other hand, lysozyme is able to mobilize other nonspecific factors for protecting the body [1]. The conducted studies revealed a significantly higher BABS in calves of the experimental group at $28^{\text {th }}$ and LABS on the $14^{\text {th }}$ day of life compared with the control animals $(\mathrm{P}<0.05)$.

\section{Conclusions}

In our study, we used a drug in the liposomal form to increase resistance of heifers and their calves under conditions of anthropogenic impact. In other words, the body was acting by complex of stress factors: human impacts and critical periods of ontogenetic development (the early postnatal period, pregnancy and calving). In these circumstances, the drug we have developed for the needs of animals: essential vitamins, trace elements and biologically active substances. That composition had positive effects on metabolic processes in animals.
Perspectives. We look ahead general picture of our investigations that consists of study the different problems of regulation of immune and also antioxidant system of different animals under conditions of technogenic stress. On the other hand, we plan to elaborate new effective drugs which will correct immunological disorders and promote the mechanisms of endogenic defense against xenobiotics in young cows.

1. Büchau A. S., Gallo R. L. Innate Immunity and antimicrobial defense systems in psoriasis. Clinics in Dermatology, 2007, vol. 25, issue 6, pp. 616-624. DOI: 10.1016/j.clindermatol.2007.08.016.

2. Chernuskiy V. G., Odinets Yu. V., Dikiy I. L.. Perspectives of liposomal forms of drugs usage in the treatment of bronchial asthma in children. Experimental and Clinical Medicine, 2005, no. 2, pp. 122-126. (in Russian)

3. Donnik I. M., Shkuratova I. A., Vereshchak N. A. The influence of ecotoxins on immune system of animals. Materials of the international scientific and practical conference "Current status and prospects of research on infectious and protozoal diseases of animals, fish and bees", Moscow, 2008, pp. 322-325. (in Russian)

4. Gelman B. B., Michaelson I. A., Bus J. S. The effect of lead on oxidative hemolysis and erythrocyte defense mechanisms in the rat. Toxicology and Applied Pharmacology, 1978, vol. 45, issue 1, pp. 119-129. DOI: 10.1016/0041-008X(78)90033-9.

5. Gorova A., Kulina S. Estimation of toxic of soils in the Chervonograd mining region with the use bioindication method. Visnyk of Lviv University, Biological series, 2008, issue 48, pp. 189-194. (in Ukrainian)

6. Kondrakhin I. Methods of veterinary clinical diagnostics. A reference book. Moscow, Kolos, 2008, 520 p. (in Russian)

7. Manning U. D., Feder A. Biomonitoring of atmospheric pollution with the help of plants. Leningrad, Gidrometeoizdat, 1985, 144 p. (in Russian)

8. Maslianko R., Kravciv Y. Colostrum of cows and its role in resistance of cows. Lviv, 2008, 124 p. (in Ukrainian)

9. Mironchik V. The method of measurement of lipid hydroperoxides in biological material. Official Bulletin, 1984, vol. 13, p. 2. (in Russian)

10. Slivinska L., Maksymovych I., Lychuk M., Shcherbatyi A. The influence of antropogenic load on the health of cows. Bulletin of Lviv National University of Veterinary Medicine and Biotechnology named after S. Z. Gzhytsky, 2012, no. 38, pp. 164-169. (in Ukrainian)

11. Vishchur O, Vlizlo V. Efectivenes of Lipogen action on the system of antioxidant defense and cell immunity in calves. Buletin of Agrarian Science, 2006, no. 11, pp. 44-48. (in Ukrainian) 